\title{
Article
}

\section{The Spirit of Time-The Art of Self-Renovation to Improve Indoor Environment in Cultural Heritage Buildings}

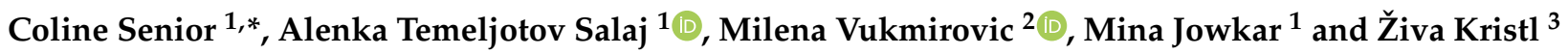 \\ 1 Department of Civil and Environmental Engineering, Norwegian University of Science and \\ Technology (NTNU), 7491 Trondheim, Norway; alenka.temeljotov-salaj@ntnu.no (A.T.S.); \\ mina.jowkar@ntnu.no (M.J.) \\ 2 Department of Landscape Architecture and Horticulture, University of Belgrade, 11000 Belgrade, Serbia; \\ milena.vukmirovic@sfb.bg.ac.rs \\ 3 European Faculty of Law, New University, 5000 Nova Gorica, Slovenia; ziva.kristl@epf.nova-uni.si \\ * Correspondence: coline.senior@ntnu.no
}

Citation: Senior, C.; Salaj, A.T.; Vukmirovic, M.; Jowkar, M.; Kristl, Ž. The Spirit of Time-The Art of Self-Renovation to Improve Indoor Environment in Cultural Heritage Buildings. Energies 2021, 14, 4056. https://doi.org/10.3390/en14134056

Academic Editors: Boris Igor Palella and Roberto Alonso

González Lezcano

Received: 28 May 2021

Accepted: 28 June 2021

Published: 5 July 2021

Publisher's Note: MDPI stays neutral with regard to jurisdictional claims in published maps and institutional affiliations.

Copyright: (c) 2021 by the authors. Licensee MDPI, Basel, Switzerland. This article is an open access article distributed under the terms and conditions of the Creative Commons Attribution (CC BY) license (https:// creativecommons.org/licenses/by/ $4.0 /)$.

\begin{abstract}
The purpose of this paper is to explore the challenges of an old low-standard urban district with a strong historical and cultural heritage and propose more sustainable renovation solutions, acceptable for the residents and municipality. The challenges of physical renovation or refurbishment are complex due to poor condition of the buildings, municipal ownership and governance, mixed management with community and low rents, which are insufficient to cover the costs. The paper discusses the proposed solutions of living standards, supported by the research in two directions: (i) available resources and reuse of materials, (ii) developing a renovation guidance for inhabitants from the building physics perspective, including indoor environment quality. Challenges related to energy efficiency are addressed from the decision-making perspective to overcome the barrier of lack of motivation to invest in energy-efficient measures at the individual and community level. The interdisciplinary approach complements engineering-focused studies with a focus on the comfort conditions and the influence of occupant habits in sustainable buildings. The methods used were literature review, case studies with observations and survey, looking to cover all technical, social, and historical aspects of sustainable renovation of cultural heritage buildings with the same level of importance. Results show that to keep a sustainable, low-cost urban living model, instructions for self-renovation are a valuable guidance for non-professional actors to make more sustainable choices. In conclusion, we can emphasize that inhabitants are accustomed to lower living standards, so the project is aimed to present the proper solutions for improvement as a balance between new sustainable technical solutions, personal self-renovation skills, habits, and health.
\end{abstract}

Keywords: self-renovation; habits and comfort; sustainable building material; cultural heritage buildings

\section{Introduction}

An increasing body of scientific literature has put the focus on energy efficiency measures for cultural heritage buildings, but this approach tends to undermine cultural values which are often described only as constrains [1]. In the extensive systematic literature review on sustainable refurbishment of historical buildings, Loli and Bertolin (2018) [2] pointed out the "Scandinavian paradox", which often shows the Scandinavian countries as frontrunners when it comes to implementing and operationalizing sustainability goals [3], but on the other hand, the scientific production on methods for sustainable maintenance and renovation of cultural heritage buildings in Scandinavia is relatively scarce [2]. Norway is quite advanced in terms of energy-efficiency renovation with a yearly rate of $2.5 \%$ of the existing building stock compared to the 13 other EU countries where data are available, which have rates between $0.5 \%$ and $2.0 \%$ [2]. However when it comes to "deep renovation" defined as interventions that fundamentally affect the buildings performance, the European rate is stagnating at $0.2 \%[4,5]$. 
The renovation of cultural heritage buildings can produce positive effects for the socio-economic regeneration of the cities [6] and boost the application of contemporary living models, sustainable management strategies, and maintenance procedures, which can balance the up-to-date requirements of energy efficiency, human comfort, and operating cost reduction [7] ensuring also energy and economic benefits [6,8].

In this regard, different studies indicated that the most critical factors for deep renovation of existing housing concern the non-technical barrier related to social, logistic, legislative, and financial constraints [9], while behavior and local cultural factors, in particular, can reduce the efficiency of the renovation initiatives, impacting on energy use, conservation state, management, and maintenance operations $[6,9,10]$. The importance of cultural heritage for the community and the specific character it has built over time are two sensitive elements that need to be combined with the contemporary expectations and responsible and sustainable lifestyle.

For policy makers, supporting self-renovation projects of residential buildings can contribute to lessen social exclusion and spatial segregation and encourage tenants to feel a sense of responsibility for their dwellings [11]. However, the lack of technical and legal knowledge among residents combined with the high costs are still major barriers in the implementation of energy efficient renovation measures [12,13]. In addition, some of the researchers emphasize the lack of motivation as a barrier for more sustainable renovation solutions [14-16], and proposing the focus on social sustainability aspects [17], more concretely: 'factors affecting participation' [18,19], 'relationship between participants' [20-22], 'engagement strategy' [23-25], and 'influence of participation' [26-28]. As stated by Esmaeilpoorarabi et al. (2020) [29], it is important to mobilize resources, improve relationships, promote cooperation, and ultimately achieve community engagement and trust $[30,31]$

The art of self-renovation in low-income urban communities is quite unique in the sense that it transcends a purely technical approach and often constitutes an opportunity for them to feel more ownership of their homes, promote social inclusion, and strengthen community bonds [32]. Financing and education of workforce are also central challenges that need to be addressed [12]. The social aspects are widely underrepresented in energy research, and although there is no question that technological engineering studies are of utmost importance to improve technical performances of buildings, due to the fact that energy-efficiency relies on human actions and informed choices, more interdisciplinary research is needed to include a softer approach and address social barriers and drivers to a successful energy transition [33-35]

\subsection{National Regulations for Conservation of Cultural Heritage Buildings}

The purpose of building protection is to preserve our sources of cultural heritage and history. Building protection became a formal matter in Norway in 1913 when the first national antiquarian was hired. Since then, it has been the Directorate for cultural heritage national antiquarian that has been responsible for cultural heritage policy [36]. In Norway, there is a broad political will to preserve cultural heritage buildings [37]. It points out further that the preservation of cultural heritage can contribute with knowledge and input to sustainable resource management by providing insight into how environmental problems have affected our patrimony and give a better understanding of how they can be solved. About listed buildings, it says: "From a long-term socio-economic perspective, preserving valuable parts of the building stock rather than demolishing and rebuilding can be significantly more profitable" [37].

The Norwegian Planning- and Building Act § 31-1 states that when doing renovation or rehabilitation, the municipality shall ensure that historical, architectural, or other cultural value associated with a building is preserved as far as possible. Nevertheless, there is a challenge associated with the maintenance and preservation of the protected building stock due to the ever-increasing demands for lower greenhouse gas emissions [38]. 
The existing building stock in Norway accounts for around $40 \%$ of the total energy consumption in the country, $22 \%$ of which is for residential and $18 \%$ for non-residential buildings [39]. In addition, most buildings built before 1950 were without insulation, which makes both protection and improvement of this building stock challenging. Fulfilling the requirements related to energy savings could mean major structural interventions and may lead to changes that affect cultural historical values of the building [36].

\subsection{Improving Energy Efficiency in Existing Buildings}

According to Ugarte et al. (2016) two of the main problems that low-standard households need to face as a consequence of low energy efficiency are extreme indoor temperatures and high humidity levels. Rehabilitation could address these problems by taking measures with three main outcomes: improvements in indoor air quality, humidity levels, and indoor temperature [40]. For this matter, retrofit programs may focus on a weatherization based on changes in the shell of the building, such as insulation of facade wall, ceiling and basement, facade painting, or replacement of windows and doors [41,42].

Given the environmentally friendly nature of wood, its low maintenance cost, and broad accessibility, wood is one of the most renewable materials in construction [43]. However, when it is used in building facades, it needs careful treatment and maintenance to minimize thermal and humidity discomfort sources in buildings. Energy wastage in the facade tends to be derived from humidity, since it provokes expansions and contractions of the material and mold growth, causing degradation of timber. From an environmental point of view, one of the best ways to protect wood is with linseed oil [44]. It saturates the external layer of the wood, so that it is impossible for water to penetrate the structure. Moreover, it allows water kept inside to evaporate [45]. It is important to plan the functioning of the building envelope for the future degraded climate conditions; in northern Europe, climate adaptation has to take into account moisture resistance (due to increased precipitation) and slight increase of temperatures [46,47].

When refurbishing the wooden structure, two main aspects need to be considered. First, if replacement of a timber member needs to be made, the new item must belong to the same species of wood and have the same quality. Secondly, it is also recommended to use the same (or similar) techniques that the original craftsmen used to convert the timber and assemble it [45].

This way, the identity of the building can be preserved. Moreover, some materials should be avoided or, at least, reduced to a minimum. Such as epoxy resins, steel reinforcements and plastic paint for coating [45].

Existing retrofit programs for low-standard buildings are based on weatherization of households; this way comfort improves and costs are reduced [48]. Weatherization is usually focused on changes in the structure, as insulation of ceilings and walls, air sealing, and duct sealing, and the electricity savings can reach up to almost half the original price [41]. Some of the actions that can be taken in order to achieve a good weatherization are $[42,49]$ :

- Insulation of roof or upper ceiling.

- Insulation of façade wall.

- Insulation of basement ceiling.

- $\quad$ Painting and mending the façade.

- $\quad$ Replacement of doors and windows.

- Use of hybrid HVAC systems.

Regarding the refurbishment of doors and windows, they play an undoubtable role in the ventilation and weatherization of a household, but sometimes their high prices might keep the owners from fixing them. Anyway, it is a key element to address, as old doors can be leaky and have extremely poor insulation; similarly, single glaze windows are inefficient and should be switched to double-glazing or interior storm windows which provide moderate insulation and avoid air infiltration [41]. 
Insulation is a key element in order to achieve a good energy efficiency level. Some natural and renewable materials have been proved to have a great performance as insulating materials, presenting important advantages regarding costs, ecology, and energy savings, if compared to traditional materials.

Natural fibers, such as technical hemp, jute, and flax have very good mechanical, acoustic, and thermal insulation properties. Moreover, they can be combined in different proportions and be useful in façades, roofs, floors, partition walls, and external walls [50]. Natural fibers, such as technical hemp, jute, and flax, have very good mechanical, acoustic, and thermal insulation properties. Moreover, they can be combined in different proportions and be useful in façades, roofs, floors, partition walls, and external walls [50].

Some additional costs can derive form the insulation of the façade, since activities as scaffolding and painting cannot be overlooked and homeowners rehabilitating a building exterior need to pay for them no matter what [42].

Other non-structure related improvements that could be applied are [42]:

- Installation of a low temperature boiler.

- Installation of wood pellet or wood chip heating systems (biomass heating systems).

- Insulation of heating pipes.

- Installation of solar heating collectors.

- Installation of heat pumps.

This said, it is clear that some good weatherization methods can be decisive for inhabitants of the building, not only in economic terms but also healthwise, as inadequate heating, cooling, or ventilation of the spaces can be a life-or-death issue $[51,52]$.

\subsection{The Scope of This Study}

The scope of the study, considering the transformation of historical and cultural background of Svartlamon, poor housing condition, reuse of materials, insufficient funding, and existing self-renovation model, aligns with the New Bauhaus European initiative which vouches for a softer approach to the challenges in reaching sustainability goals. The European Commission's initiative aims to bridge the world of science and technology with the world of art and culture by developing affordable and accessible living spaces, striving to improve quality of life and highlight simplicity, functionality, and circularity of materials while accounting for the need for comfort and attractiveness in citizens' daily life [53]. Building upon this initiative, this study focuses on three principles:

(i) To keep the alternative community acting as a pioneer in terms of sustainable, low-cost urban living models and retaining the strong identity of the district;

(ii) To advance the relationship between the community and the municipality by improving the co-management model facing the safety building level as a foundation for self-renovation outset;

(iii) To self-renovate the houses more in accordance with sustainable refurbishment principles.

The paper aims to address some of the challenges linked to unsupervised self-renovation work that can result in alteration of the cultural heritage buildings, negative consequences of the maintenance backlog, and unsustainable technical solutions. At the same time, this study looks into approaches that will increase the sustainable renovation rate that is currently lagging behind due to socio-cultural barriers [54]. The case study proposed in this paper focuses on "soft approach" to energy renovation. This paper deals with energy efficiency from the decision-making perspective addressing the challenge of lacking motivation to invest in energy-efficient measures. The interdisciplinary approach complements engineering-focused studies with a focus on the comfort conditions and the influence of occupant habits in sustainable buildings. It proposes a practical self-renovation guidance for residents with a focus on sustainable technical and technological solutions, focusing on indoor environment, health, and wellbeing. This is motivated by a gap identified in previous studies that revealed communication challenges between public authorities and residents in the field of energy retrofitting of cultural heritage buildings that resulted in 
decaying buildings rather than improving their sustainability [13]. This can be also seen as an urban experimentation (Newton and Frantzeskaki 2021) case which can be replicable for similar circumstances.

The main research question is how to raise the self-renovation standards of cultural protected though poorly maintained area. The aim is to explore how it is possible to refurbish the houses, keeping all the existing aspects of the community, the history, the culture for re-use of materials, and the low budget and adding new ones like thermal insulation and general improvements of the indoor environment. The analysis of the physical properties of buildings such as ventilation, lighting, thermal weaknesses, and thermal insulation will be explained, in order to propose appropriate measures to meet the growing demand for a pleasant indoor climate while safeguarding the cultural heritage values. In addition, a survey conducted among residents of a low-standard urban community is presented to understand the opportunities and challenges of sustainable self-renovation of cultural heritage buildings.

This paper is structured as such: Section 2 presents the overview of the material and methods used for the study; Section 3 shows the study results; Section 4 presents a guidance for sustainable self-renovation in accordance with the theoretical and empirical background, and Section 5 concludes with the main findings.

\section{Materials and Methods}

To address the research question, we investigate in three directions: (i) improving the living standards and culture of a low-income intentional community, (ii) widening the reuse of materials as a part of circular economy solution, and (iii) finding high quality LCC solutions for specific problems. A number of buildings with a focal point on observation in the intentional community of Svartlamon in Trondheim, Norway, were chosen as the case study. This was combined with multiple on-site visits and a questionnaire survey. The case of Svartlamon was selected for its uniqueness and self-organized maintenance and operation system. The economic, socio-cultural, and environmental challenges posed by its ownership structure and eventful history as well as the subversive nature of Svartlamon will be presented in the following section. The present study is a result of several projects running at the Norwegian University of Science and Technology with master's students since 2018.

The data collection and observation have been conducted in collaboration between master's students and the authors of this paper during the spring and fall semesters, from 2018 to $2020[55,56]$. Initial data about Svartlamon's historical and cultural background were collected through informal meetings with Svartlamon housing foundation (Svartlamon boligstiftetse) and desk research at Trondheim Municipal Archive Center (Trondheim Byarkiv). Observation of indoor has been organized by Svartlamon housing foundation several times per year for the students and the research team. The observations of the outdoor environment were taken and documented whenever was needed.

A questionnaire survey was designed to investigate the living conditions in Svartlamon, the self-renovation work organized and done by residents, and their perception of sustainable technologies. The questionnaires included 4 sections; the first section collected demographic information such as age, employment status, composition of the household, living period in Svartlamon, the affiliation to a sub-community, and types of facilities respondents shared with others (bathrooms, toilets, kitchen, living room, laundry room, etc.) The second section on the living conditions consisted of questions about social aspects of the community life, motivation factors for living in Svartlamon, opinions on possible changes or improvements that could be made, and their perception of the core-values of the community. The third section collected data on self-renovation habits and culture, the respondents' involvement in such work, and their will to participate more in the future. The last section of the questionnaire addressed the available technologies within the households as well as their perception of innovative sustainable technologies. 
The questionnaire was distributed in digital and hard copy versions to all inhabitants in Svartlamon (ca. 200 people), and answers from 24 people were collected. A qualitative analysis of the results was then conducted by the authors in order to serve as a basis for the recommended renovation measures that respect and reflect the spirit of the Svartlamon community.

\section{The Overview of the Study Area}

Svartlamon is a neighborhood in the city of Trondheim, Norway, with a strong presence of listed buildings (Figure 1). It is inhabited by an alternative low-income community and regulated as the first urban ecological research area in Norway, which makes it a particularly relevant experimental case to explore the challenges of sustainable renovation of cultural heritage buildings.

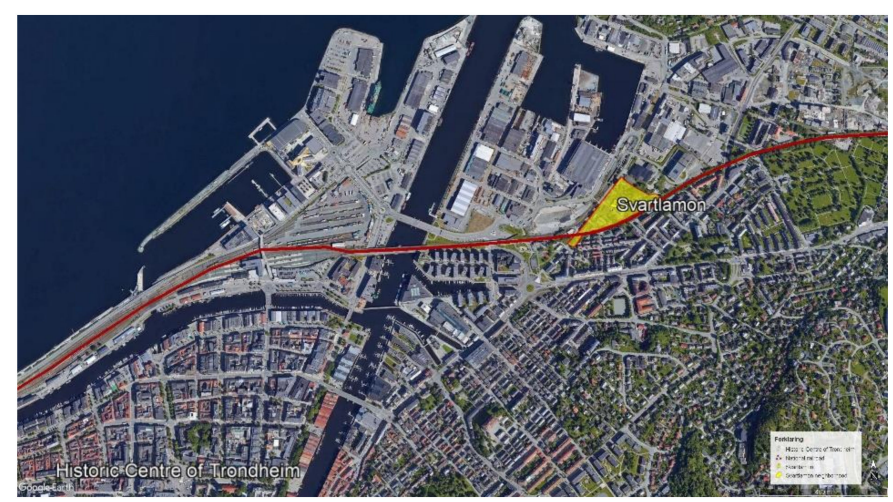

Figure 1. Trondheim Historic Centre, Svartlamon, and National Railroad $\left({ }^{\circledR}\right.$ Google 2021, edited by authors).

The origin of Svartlamon dates back to 1860, established as a settlement in the outskirts of Trondheim for dock workers, sailors, and workers from nearby factories. Due to railway construction in 1889, the area was exempted from the bigger district Lademoen and became the dirtiest and poorest part of it; thus, it got nicknamed Svartlamon or "black" Lamon [57]. There was no water or sewage system, which made it a sullied residential area with precarious living conditions. During World War II, some houses were demolished to allow the construction of the Dora II Bunker. Even though Svartlamon was later incorporated into the city, the basic infrastructure was severely lacking (Figure 2) [58]; therefore, by 1980, the municipality changed plans for this district to be demolished and become an industrial area. As the demolition operations started, a small area comprising of wooden houses remained untouched and was squatted by outcasts and criminals.

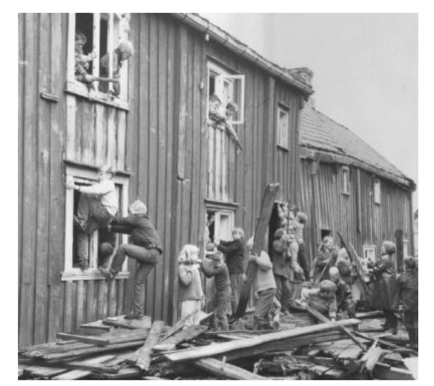

Figure 2. Svartlamon in 1964 (Trondheim Municipal Archive Center).

However, in the 1980s the cultural heritage character of the houses was brought to the attention of a community of artists and activists who occupied the houses and settled in, starting the first wave of basic renovation to repair damages caused by negligent tenants [59]. They made the area livable again and started their own alternative-living 
community. Svartlamon is also defined as an intentional community [60], a community 'which choose to live together with a common purpose, working cooperatively to create a lifestyle that reflects their shared core values' [61].

In 1990, the municipality attempted once more to tear down the Svartlamon area arguing that the houses were unfit for living and had not met the regulations in place for residential buildings. This marked the beginning of a fight between the municipality and the residents who organized themselves into the Svartlamon Residents' Association, 'Svartlamon Beboerforening'.

After long years of discussions and conflicts, the municipality decided in 2006 (Figure 3) to consider Svartlamon as an experimental urban ecological area, the first of its kind in Norway [62,63]. Since 2001 the Housing Foundation 'Svartlamon Boligstiftelse' has been acting as a steering organ, collecting the rents, and managing the everyday operations of the community. It also bridges communication between the community and their municipal landlord.

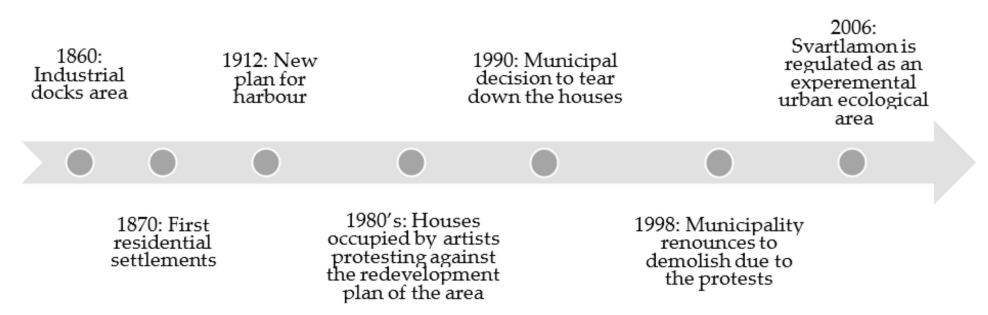

Figure 3. Timeline of Svartlamon's history (by the authors).

The challenges it faces today are caused by the long period of neglecting the area, mixed governing and managing structure, unclear distribution of responsibilities, and insufficient maintenance funding as the income is based on low rents. All these lead to poor infrastructure in indoor and outdoor housing condition. Regardless of the very active and social oriented community, their self-renovation attitude and habits and their demographic background with lower income and short-term tenants' contracts lacked enough security to search for high quality solutions and resulted in the multiplication of quick fixes rather than long-term solutions. Today, the contract period is extended to twenty years, which gives better planning foundation for more sustainable renovation solutions and future development.

In line with the aforementioned and having in mind the presented history of its origin and basic function, the settlement can be characterized as industrial heritage with significant social value, as important evidence about the life of ordinary people and their identity [64-66]. In addition, it has a technological and scientific value with regard to the history of manufacturing, engineering and construction, as well as a significant esthetic value in terms of architecture, design, and planning. These values exclusively refer to industrial heritage, its materials, components, equipment, and method of installation in industrial environments, as well as written documentation and intangible records related to the memory of the people and customs [67].

Svartlamon is covered by zoning plan R0219b, which came into effect on the 27th of June 2006. Based on the zoning plan, urban ecological efforts at Svartlamon include both physical and process related efforts. The physical experiments involve testing of new and affordable solutions in housing types, technology, and architecture. With the main focus on utilizing physical resources in the area [68].

Process-related trials, on the other hand, involve testing new planning, management, rehabilitation, and collaboration processes, with the main focus on utilizing the human resources in the area. According to the zoning plan, the concept of urban ecology therefore implies a holistic view where development in the area is based on an interaction between the physical and human resources, where one cannot be seen separate from the other [68]. 
Further on, the zoning plan states regulations in regard to refurbishment at the area. According to $\S 3-5$, in the zoning plan, it is specified that: "Existing buildings shall be preserved except for the buildings marked as demolition objects in the planning map of the area. For existing buildings, no major reconstruction, extensions or facade changes can be made without this being presented to the Cultural Heritage Management Office in advance." [68]

In this study, we highlight both the technical, social, and cultural aspects with equal importance. This combined approach of sustainable renovation of cultural heritage buildings is seen as an added value to tackle the challenges in this domain.

\section{Results}

\subsection{Case Study Description-Observation}

At Svartlamon, there are a total of 25 residential buildings with 130 dwellings/tenancies. The total gross area of the residential buildings is approximately $7000 \mathrm{~m}^{2}$. About 200 people live in the dwellings rented by svartlamoen boligstiftelse by the municipality. There are also four commercial buildings, and the gross area that the culture and industry foundation rents from the municipality constitutes ca $2500 \mathrm{~m}^{2}$ (Table 1).

Table 1. Characteristics of Svartlamon.

\begin{tabular}{|c|c|c|}
\hline \multirow[t]{6}{*}{ Aerial picture of Svartlamon $\left({ }^{\circledR}\right.$ Blom $)$} & area & Ca. $27 \mathrm{~km}^{2}$ \\
\hline & population & Ca. 200 inhabitants \\
\hline & $\begin{array}{l}\text { type and number of } \\
\text { buildings (year } \\
\text { of construction) }\end{array}$ & $\begin{array}{l}25 \text { residential buildings and } \\
4 \text { commercial buildings }\end{array}$ \\
\hline & type and number of flats & 130 dwellings \\
\hline & main infrastructure & $\begin{array}{l}\text { Kindergarten, culture } \\
\text { house, shops, railways, } \\
\text { and roads }\end{array}$ \\
\hline & $\begin{array}{l}\text { maintenance funding } \\
\text { (per year) }\end{array}$ & $\begin{array}{c}\text { Housing Foundation ca. } 1.3 \\
\text { M. NOK + Municipality ca. } \\
1.2 \text { M NOK }\end{array}$ \\
\hline
\end{tabular}

About 80 people work in varying positions in Svartlamon. In addition, the kindergarten is managed by the municipality. The area is regulated as special conservation area and has about 35 antiquarian classified buildings (residential buildings and outbuildings) [69].

Svartlamon is a district located to the east of the Trondheim city center, which hosts in addition to the residential buildings, a reusable shop, free shop, cultural festival, concert venue, kindergarten and book café. Most residents share some facilities like bathrooms (toilets and showers) and kitchens. The old houses are wooden and brick buildings. Inhabitants tried to renovate some parts of the buildings since their construction in the 19th century, but the buildings are in a general bad condition now. Lack of money and complex organization between the municipality and inhabitants lead to insufficient investments in maintenance of the buildings and regeneration of the area. The buildings are owned by the municipality, and since 2001, the housing foundation has been responsible for collecting rents and ensuring the maintenance. This was formalized in the contract that binds the foundation and the municipality, by which the municipal landlord transferred all its responsibilities for maintenance and preservation to the foundation. Today, the foundation manages 151 leases divided into 35 houses with about 200 people living there. The foundation has three people working full-time, a manager, a carpenter, and an electrician. The money collected by the foundation finances the salaries of the three employees, renovations, and maintenance operations. In order to keep the rent as low as possible, residents are expected to do as much work as possible by themselves. The Housing Foundation has a permanent office and meeting place on site. In addition, in 1990, Svartlamon residents' association was founded with the purpose to preserve the houses and to defend low-income people's right to live downtown. Everyone who has a lease with the Housing Foundation is automatically a member of the Residents' Association. They 
have monthly meetings and govern with a flat structure and consensus. The residents of Svartlamon have a leading role in the renovation. They manage to do almost everything by themselves with low budget, reusing materials from the old houses from other parts of Trondheim and trying to keep the buildings in their original state. The focus of this study is mostly on the technical and technological aspects, but reflecting also the economic, organizational, social, cultural, and historical ones.

Svartlamon is located close to the city center of Trondheim, with a climate type dominated by the winter season, cold period with short daylight, relatively little precipitation which is mostly in the form of snow, and low humidity. It is located north of the humid continental climate. There is an average of 272.0 days of precipitation. The average temperature for the year in Trondheim is $4.8^{\circ} \mathrm{C}$. The warmest month is July with an average temperature of $13^{\circ} \mathrm{C}$. The coolest month is January, with an average temperature of $-3^{\circ} \mathrm{C}$.

Wooden buildings (Figure 4) are houses with bedrooms and kitchen. Each house does not necessarily have a bathroom. The community shares few bathrooms. Most of the houses were built at the end of 19 century; they are now deteriorated even though people tried to keep them in a satisfactory condition. Most of them are two-story houses. In the area, we can notice a sloping terrain, some gardens, pebbles on the ground, and brick floor in some paths. There are no paved roads or sidewalks between houses. The site is located near the Strandveien road with cars and bus. There is some lighting next to the main road but not in the smaller paths between houses. There is also the railway right next to houses. Most of the houses do not have any basements except the storage room for the ancient milk shop.

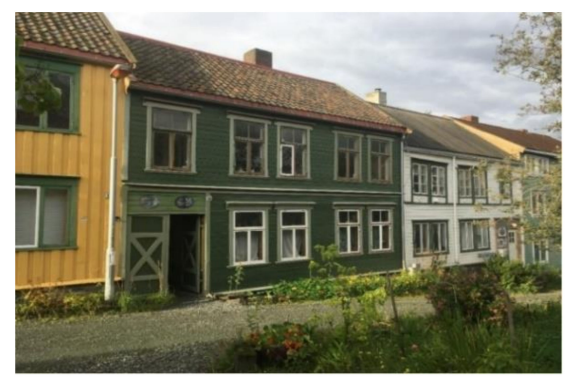

Figure 4. Svartlamon wooden buildings (NTNU).

Foundations are in bad condition. Houses have many windows, but they are damaged, showing problems with condensation and humidity. All the facades are painted; however, the painting is very old and is deteriorating (Figure 5). Roofs are not insulated, and all houses have a steep roof. Many houses have tile roof. Clay tiles are a traditional kind of roofing material, it is a material that is both widely available and easy to shape into forming a channel to direct the flow of water. Some of the houses have a corrugated metal roof which is inexpensive and quick to install. Mainly, the rainwater gutters and downpipes are in good condition close to the roof, but the lower parts are worse (leakages), causing constant humidity on the walls, allowing moisture to seep into the houses, so molds, fungus, and mosses are spotted. They affect the health and well-being of people. The façades are complicated to insulate due cultural protection, so the design of the facades and windows should be original. Walls, doors, windows, partitions, and finishes are wooden and old. 


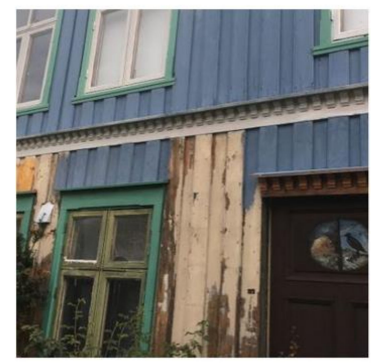

Figure 5. Deteriorating façade (NTNU).

Many walls are not straight, and they lean (Figure 6), likely because the houses were built on poorly compacted embankments or on a heterogeneous soil. No drainage systems could be seen around them. Some of the load bearing elements are rotten. Even some entry doors are not straight. Most of the houses do not have any bathroom, and the only sink in their house is the kitchen one. The houses with bathrooms share them. The plumbing system is old and partly maintained but not to the standards that we can find in newer houses. The electrical system is at its full capacity, old but safe.

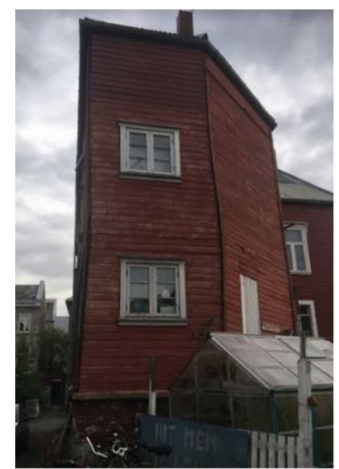

Figure 6. Leaning house (NTNU).

A typical example of housing block is presented: two buildings Strandveien 19 and 21 (Figure 7), from 1893, with four flats each, shared facilities in the common basement, and a shop in the ground floor. The foundation material is stone; basement walls are made of brick, and upper floor levels have a wooden structure. During the time only some small interventions were done, and foundations were stabilized in 2001; a wind barrier on the north façade was installed in 2016, and the damaged wooden panels were replaced (Figure 8). Both houses need major refurbishments as some foundations and walls are falling apart, and the structure is in a very bad condition, showing many cracks.

A comparison of the floor plans shows some smaller changes in the usability of the space in the floors and basement. An apartment in the basement is changed to a bathroom and storage place for inhabitants, and some internal walls were removed to create a larger common space. In one of the flats in the second floor, an extra bedroom and own bathroom was built.

An analysis of technical condition is presented, based on the observation (Figure 9). The foundations of the two buildings are connected and have the same structure, consisting of stones. They support brick walls with a thickness around $0.40 \mathrm{~m}$ and a height equal to the basement height, which is up to $3.00 \mathrm{~m}$. There is no drainage system on the outer side of the walls. The inner walls structure from the basement on is carried by wooden columns. The wooden façade is made from stacked timber with a thickness of $7 \mathrm{~cm}$. 


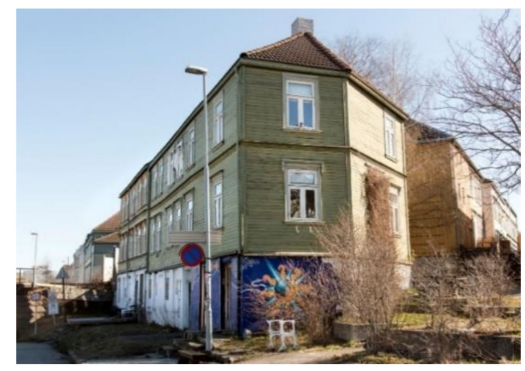

Figure 7. Strandveien 19 and 21 (Trondheim Municipality, 2016).

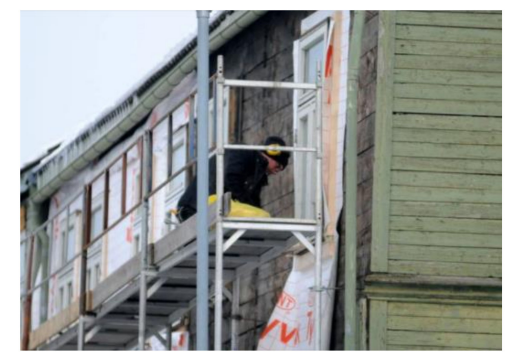

Figure 8. Renovation of the façade (Trondheim Municipality, 2016).

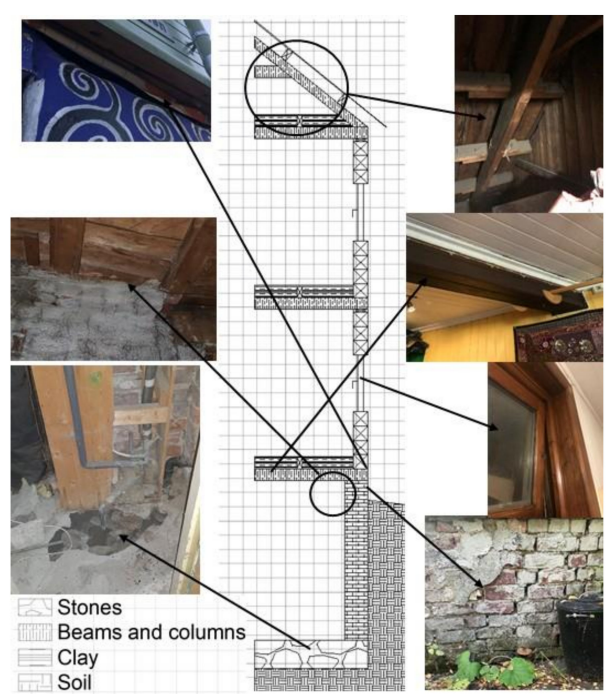

Figure 9. Illustrated section of the building in Strandveien 19 (Sekkal, 2019).

The structure of the slabs is made of primary beams resting on the columns and the brick wall. The wooden slab is made in classic form: secondary layer of beams with space of $50 \mathrm{~cm}$ between each, another layer for wooden panel floors, and clay or gravel in between as insulation. The frame of the buildings is classic with a wooden truss, which is supported by the columns in the walls. Above the trusses, there are purlins that support perpendicular wooden boards. The distance between the trusses is more than $6 \mathrm{~m}$.

Windows are not the original ones, and they are in simple or double glazing. However, we saw that some frames are damaged mainly due to humidity.

Almost no insulation is found, and it is only in the basement, in front of the brick wall (15 cm of glass wool). Some of the residents put an internal insulation.

The walls have many cracks both inside and outside the buildings. A large crack in the cladding of the north façade between the two houses extends along the entire height of the ground floor, and the thickness is from 1 to $2 \mathrm{~cm}$. From documented material, it is there from 2012 and is still the same size, without any changes (Figure 10). There are many other 
smaller cracks in the brick walls, missing cement binders and in the wooden walls as well. On the north façade several humidity traces could be seen (Figure 11).

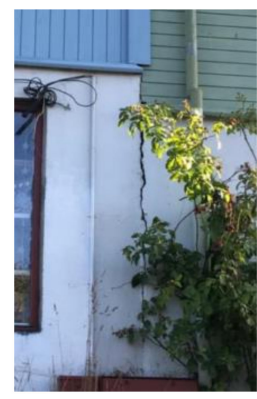

Figure 10. Crack between the buildings Strandveien 19 and 21 (NTNU).

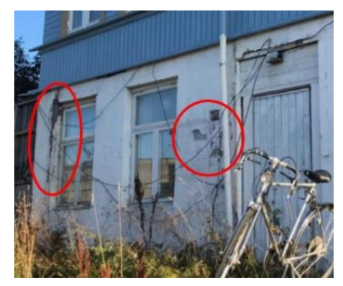

Figure 11. Humidity damage (NTNU).

The situation extended for a longer period could cause the structural and health problems due to humidity indoor (Figure 12), which could freeze during the winter, or formation of molds and fungi. In addition, the cladding contact between the brick and wooden wall is not tightened enough (Figure 11, upper left corner). There are some damages on the south wall: some pieces of bricks are falling; there are cracks between the bricks with missing binders and traces of humidity coming from the outside, i.e., from the soil (the bedrock in Svartlamon is very shallow). The analysis shows various causes of humidity in the wall: cracks outdoor, poor cladding condition, no drainage, capillary rise, bad condition of the gutters causing too much water streaming on the façade, and the wooden board above the wall of the ground floor does not play its part to 'drop' off water. The humidity traces are located at the top of the wall or on the ground, behind the cracks, in the contact area of two different cladding materials, and behind the wooden façade, panels are not tightened enough and have no vapor barrier.

The ventilation is not efficient in the buildings. The air exchange is only through the doors and windows, somewhere through leaks in the walls, and small extractors in bathrooms (Figure 13). There is no ventilation system in the kitchen.

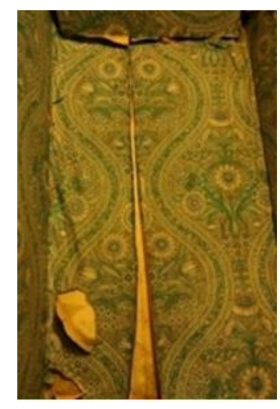

Figure 12. Indoor wall in one of the rooms (NTNU). 


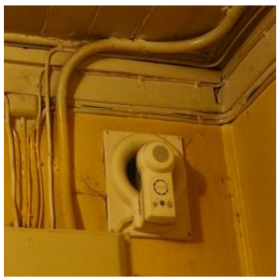

Figure 13. Integrated humidity control, occupancy sensor, and downtime (NTNU).

The acoustic is problematic, and there is a lot of sound transmission. During the visit to one of the apartments, the discussion from another one was heard as well as a washing machine from the common stairs. Inhabitants made an agreement between the residents to respect a certain schedule of "making noise". The noise could be heard through the windows of the north façade, which is facing to the railway.

The electrical system is old, safe, but insufficient, so they should consider new equipment. They use mostly electrical heaters. The lighting conditions are quite poor.

The municipality conducted an evaluation of the maintenance backlog of the building stock of Svartlamon in 2016. Their findings, which align with our on-site observation (Table 2), support the evidence that the available funds for maintenance were very low compared to the required renovation work (examples given in Table 3 for Strandveien 19 and 21).

Table 2. Problems of the building stock based on site-observation.

\begin{tabular}{cccccc}
\hline $\begin{array}{c}\text { Foundation, } \\
\text { Basement }\end{array}$ & Facade & Walls & Floors & Windows & $\begin{array}{c}\text { Basic } \\
\text { Infrastructure }\end{array}$ \\
\hline $\begin{array}{c}\text { humidity, } \\
\text { stability, cracks, } \\
\text { missing } \\
\text { drainage }\end{array}$ & $\begin{array}{c}\text { cracks on the } \\
\text { wall, rotten } \\
\text { wooden panels, } \\
\text { deteriorating } \\
\text { paint }\end{array}$ & $\begin{array}{c}\text { cracks on the } \\
\text { walls, molds, } \\
\text { fungus, rotten } \\
\text { elements, } \\
\text { humidity }\end{array}$ & $\begin{array}{c}\text { noise } \\
\text { disturbance } \\
\text { between floors }\end{array}$ & $\begin{array}{c}\text { simple glazing, } \\
\text { humidity } \\
\text { damages on } \\
\text { wood frames }\end{array}$ & $\begin{array}{c}\text { missing toilets, } \\
\text { baths }\end{array}$ \\
\hline
\end{tabular}

Table 3. Estimated renovation costs compared to available funds (Trondheim Kommune, 2016).

\begin{tabular}{ccc}
\hline & Further Improvement Costs & Available Funds \\
\hline Strandveien 19 & 709,090 NOK & 126,270 NOK \\
\hline Strandveien 21 & 591,936 NOK & 105,408 NOK \\
\hline
\end{tabular}

In the case study of Svartlamon, different local resources were found. The observations revealed several workshops available at no cost to the residents; photos of the workshop are shown in Figures 14 and 15. Here, the renters have both materials and tools that can make it easier to maintain their home and houses. There is also a dedicated group that manages the workshops.

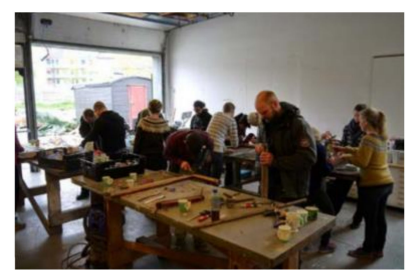

Figure 14. Workshop session on window restauration (Svartlamon residents association, 2016). 


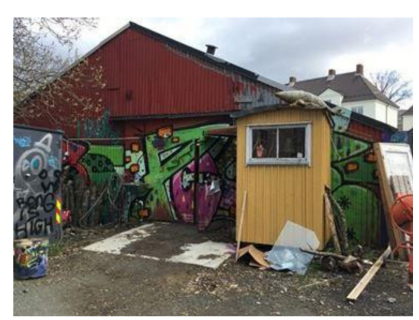

Figure 15. Workshop at Svartlamon (NTNU).

The workshop voluntary group manages the workspaces (Figure 15) at Svartlamon with associated tools, materials, and a recycling stock that is available both to the residents and to the residents association.

They receive a lot of recycled materials from both outside and inside Svartlamon. From time to time, Svartlamon also receives old material and equipment from houses that the municipality is tearing down. The idea is that access to tools and materials should stimulate reuse and local refurbishment. It is stated as a cautious estimate that the voluntary group organizing the workshop produces about 250-300 h of work per year [69].

Based on their own observations and this information, the students decided to investigate solutions that could improve the living standards in the buildings in a more sustainable way with respect for the low-budget and self-renovation culture deeply anchored in the Svartlamon community.

\subsection{Results of the Survey}

Based on the results of the questionnaire, relevant information regarding the living conditions in Svartlamon are presented in this section. 54.2\% of the respondents share bathrooms and toilets with other households. The respondents rated their relationship to their neighbors above average (on a scale from $0-6,100 \%$ rated it above 3 ; with $58.3 \%$ rating it as a 6/6). The main factors that influenced their choice to move Svartlamon were Social aspect/sense of belonging (83.3\%), Freedom (79.2\%), Budget/economic reasons $(66.7 \%)$, Having friends/family that were already living in Svartlamon (66.7\%). To the open question on what they liked the most about living in Svartlamon, the social aspects came out the most, including community feeling, local democracy, shared facilities and green areas, economic freedom (non-binding leases, possibility to settle in a mobile home, no mortgage, cheap rent that allow to focus personal investments elsewhere, e.g., "pursuing their dreams"), general feeling of freedom (to set up art installations, start new activities and events, DIY projects). To the open question on whether they would like to change anything in Svartlamon, most respondents would like to have an even bigger community engagement, i.e., that more people would actively participate in the collective activities and decisions.

The interesting thing about the self-renovation culture in Svartlamon is that a majority of the respondents have experience in renovation work (Figure 16).

Where you ever invoved in a renovation/ refurbishment project? 24 answers

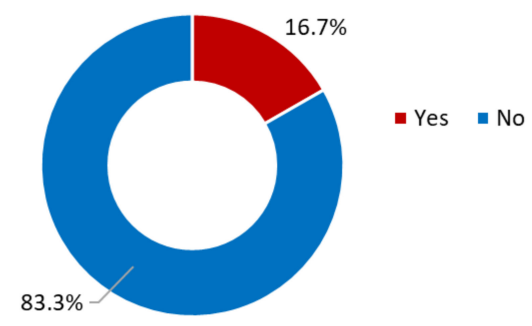

Figure 16. Participants' involvement in renovation/refurbishment projects. 
Furthermore, results point towards a strong community aspect of these projects with respondents being involved not only in their own house renovation but also those of other residents (Figure 17), and a further engagement of the community at large beyond the household (Figure 18).

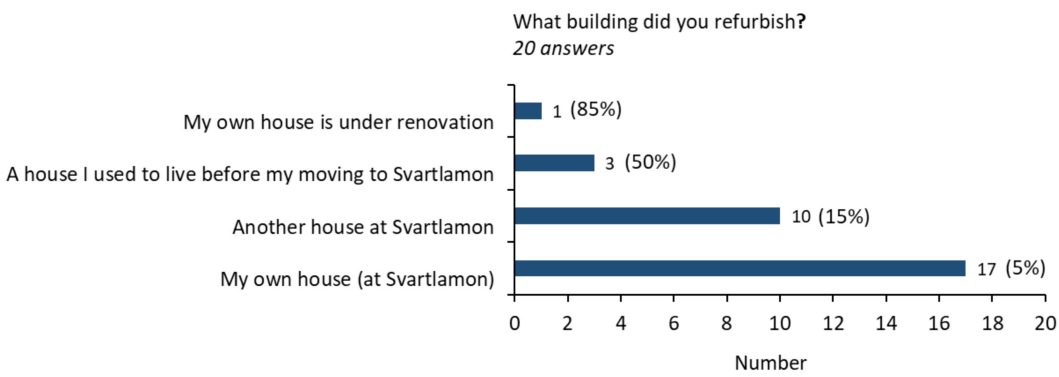

Figure 17. The type of buildings and the participants involvement in renovation plans.

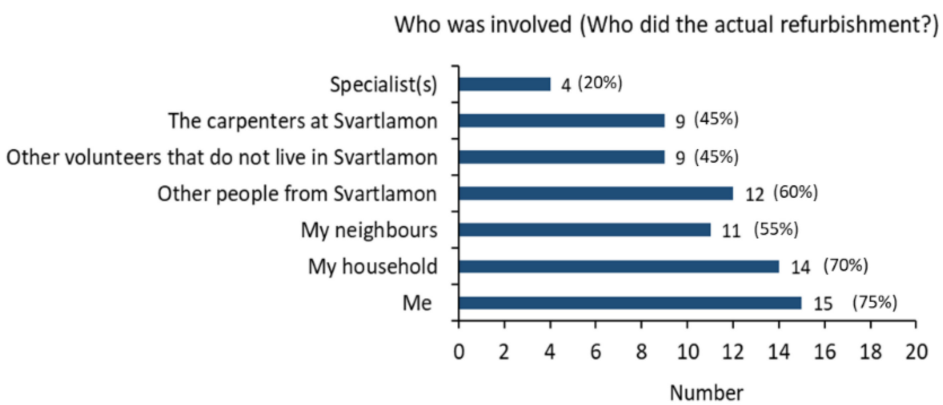

Figure 18. Involved groups in renovation plans.

However, most of them did not discuss the project with the community beforehand (Figure 19), and a vast majority expressed their will to be involved in future projects (Figure 20).

Would you like to be involved in any future refurbishment project at Svartlamon? 24 answers

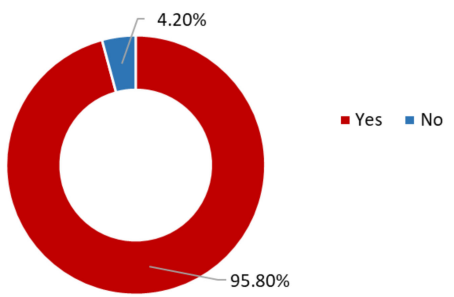

Figure 19. Participants interest in involvement in future renovation plans.

Did you discuss the refurbishment with the community of Svartlamon beforehand? 20 answers

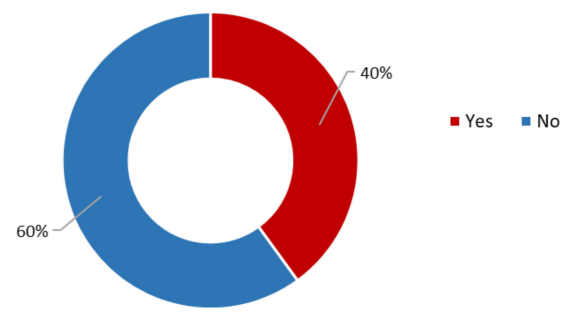

Figure 20. Respondents' engagement with community before renovations. 
Regarding the technologies available to their household, results show that the most basic needs are met, while more sustainable technologies are not (Figure 21). However, a majority of respondents expressed no need for new technologies (Figure 22).

From the open question about the use for new technologies in their daily life, some respondents expressed a will to have more sustainable energy sources such as solar panels combined with thermoelectric generator, heat pumps, and bio toilets.

"We are saving up to buy a thermoelectric generator which will help us utilize our solar energy system better during the dark months of winter, via the wood stove. We are also saving up for a bio/compost toilet". (Survey respondent)

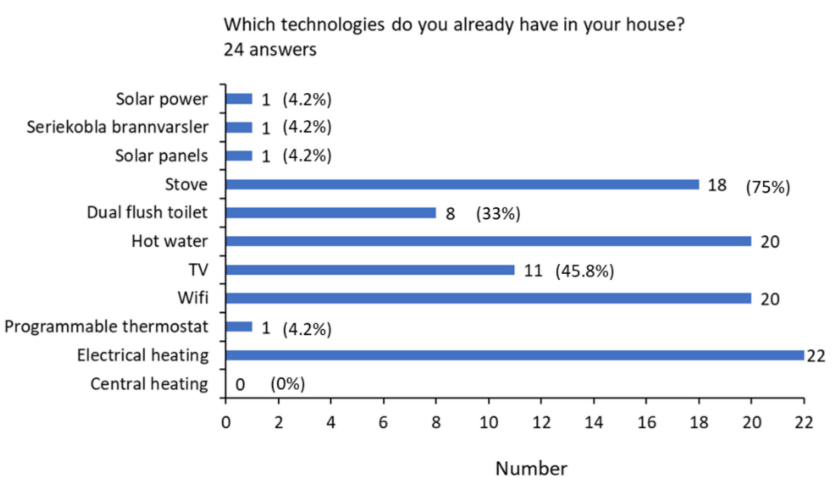

Figure 21. The technologies available in the respondents' houses.

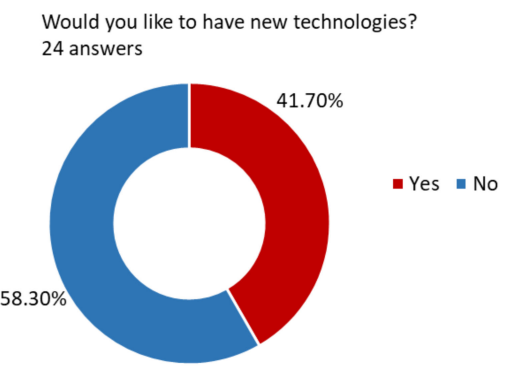

Figure 22. Participants' interest in applying new technologies.

Others expressed a need for keeping up the basic comfort with examples of kitchen fans and floor heating systems. For the majority who expressed no need for new technologies, respondents expressed a will to keep the simple living standards as they are for cultural reasons or lack of space in their dwellings.

"I have what I need", "My house doesn't need anything else, nor is our house big enough",

"The rooms are original 1880s, and I like the quiet atmosphere in the rooms". (Survey respondents)

An analysis is designed to address challenges and find solutions from different perspectives that could be useful for inhabitants with low budget and a 'do it yourself' mindset.

The students covered different areas, such as indoor temperature, air quality, noise disturbance, energy consumptions, cracked walls, fire safety, and lack of private bathrooms.

\section{Guidance for Sustainable Refurbishment for Improving Indoor Environment}

As a result of the observations and the survey, the students developed under supervision of academic and professional experts, a practical guide in form of a small magazine for residents in which they addressed each part of the sustainable renovation work (Figure 23, Trouillon et al. (2019)). 


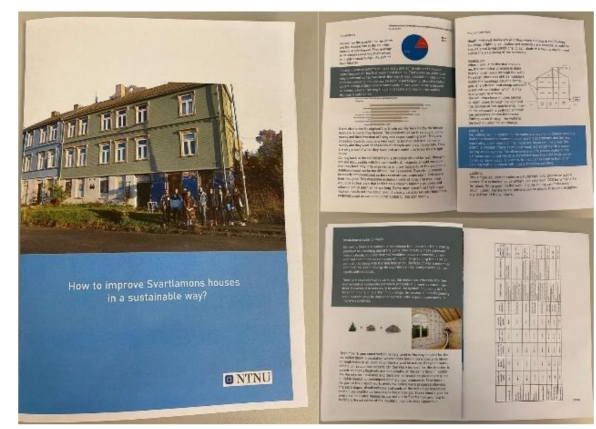

Figure 23. Practical guide developed by NTNU Students for Svartlamon residents.

The first part of this magazine recalled information about the cultural heritage background and communicated the results of the survey. Further on, each element of the sustainable renovation guide was addressed in the most practical way yet easily understandable for a non-expert audience. This practical guide provided background information on the buildings' symptoms, the importance of addressing them, the potential for reusing materials, and the possible renovation measures to be taken.

The following section goes into the details of each element covered more succinctly in the magazine.

\subsection{Reuse of Materials}

While global concerns are saving energy, protecting the environment, as well as the scarcity of resources, re-use and recycling take place in the very first steps towards a promising future. The inhabitants and the entire community of Svartlamon have a good understanding of these issues, and many of them explain that they are living in this neighborhood not only for the low rent price, but rather to live a simple life and have a low environmental impact. Furthermore, this practice is the preferred one in the community, both for economic and environmental reasons. Svartlamon could also benefit from a collaboration with Loopfront, a digital platform created in Trondheim that enables the reuse of materials in the construction industry, promoting a circular economy [70].

More specific information about the reuse of construction materials is presented below in order to provide a basis for technical guidance for non-professional residents who engage in self-renovation work.

\section{Bricks}

Brick is a robust material with a long service life. Thus, recycled bricks have great potential for use in new constructions. Recycled bricks can be used in different contexts depending on the technical characteristics of bricks. Reclaimed bricks that are frost-proof can be used for cladding in facades while those that are not frost-proof are used in a plastered façade. Bricks used over several floors must have sufficient compressive strength. The reuse potential of bricks varies for different periods of time. Bricks covered with paint or treated with surface treatment that may contain PCBs, chlorine paraffins, heavy metals and other hazardous substances should be avoided [71,72].

A project at Lilleborg in Norway shows the following figures on the cost of unit price for reuse of bricks:

- $\quad$ Demolition and cleaning: approx. 5.5 NOK/brick;

- $\quad$ Re-burning of brick with low frost resistance: approx. 3NOK/brick;

- $\quad$ Price for new brick: $3 \mathrm{kr} /$ stone.

Results of the Lilleborg project indicate that due to the costs associated with sample extraction and quality control, the reuse volume per demolition object should be at least 50,000 bricks [72]. 


\section{Wood}

Results from the project "Reuse House Trondheim" showed that wood is one of the most popular materials for reuse [73]. Re-used material groups include all types of treated and untreated wood, glued-laminated timber, and wood fiber products, where spruce and pine are the most commonly used types of wood in Norway. Wood is most often used in constructive elements. It makes up about $30-40 \%$ of the total waste during a demolition. In the "Reuse House Trondheim", approximately $85 \%$ of the timber-frame and cladding were made of reclaimed wood, and smaller wood elements like doors, window frames, and kitchen interiors were also reused [74]. It is important to keep a record of quality assurance process when re-using or repurposing wood so that the material keeps its quality and usability. Wood that should be avoided is CCA- and creosote impregnated wood which belongs to the group impregnated wood and is considered hazardous waste.

\section{Metal}

Metals such as steel, zinc, copper, and aluminum components are sorted for reuse. One should be aware that materials that belong to the hazardous waste category should not be reused. Surface treatment must be assessed against limits for hazardous substances and whether there may be a risk of leakage [74]. One must be careful about the metal components with surface treatments that contain sensing substances (asbestos, heavy metals, Pcb, chlorine paraffins).

\subsection{Indoor Environment}

In the case of low-standard buildings, retrofit recommendations are based on weatherization of households, to improve indoor comfort and reduce energy-consumption costs. Weatherization is usually focused on changes in the structure, such as insulation of ceilings and walls, air sealing, and duct sealing.

\section{Ventilation}

To have a healthy indoor environment, fresh air is required in buildings to lighten and minimize odors, to improve the oxygen level for respiration, and to increase thermal comfort [75]. Natural ventilation could be a good environmentally friendly solution in Svartlamon buildings to improve air quality as the budget is very tight and the cultural heritage must be preserved [76]. This ventilation system can not only bring in fresh air using the natural force of wind and provide a high ventilation rate, which can be cost and energy efficient compared to mechanical systems, but also (if applied properly) can provide the opportunity of accessing daylight in buildings [77].

The proposed solution implies having straight pipes (re-used when applicable) through the roof and the ceilings of the apartments in order to exhaust the polluted air from the secondary rooms (kitchens in this case). Each apartment would have its own pipe as shown in Figure 24 which refers to a possible solution for the house of Strandveien 21. Putting vents through the walls is also a good solution for air change. However, the location and orientation of these pipes are crucial in terms of controlling the airflow, pollution release rate, and the amount of fresh air coming in [78], not having vents close to the exhaust pipe, but at the opposite side to improve airflow and preferably placed facing the wind, but also not close to the windows which is a cold area. 


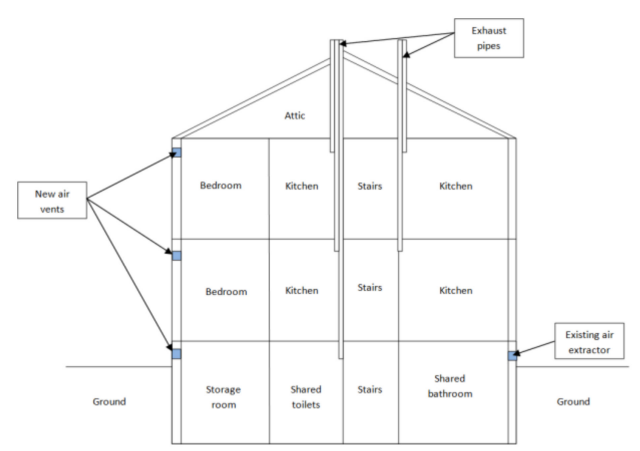

Figure 24. Simplified drawing of the proposed ventilation system for Strandveien 21 (Practical guide by Gendarme, 2019).

Ventilation outlets would be a vertical duct (at the opposite side of the air inlets) from the ceiling of the apartment to the roof of the house but also air extractors. The vertical straight pipe will evacuate hot air through the roof due to the low density of heated air.

\section{Sound insulation}

Materials which will be used for sound insulation need to be selected carefully. The goal is to prevent, or at least reduce, the sound coming from other apartments since it is the most annoying sound source. For keeping a low budget, only the walls (separating the common stairs and the apartments) and the floors (separating the first floor and the second floor) are addressed. Sound absorbent materials act as springs in a mass-spring-mass system. The sound absorbent is a soft, porous material that dampens sound and which is placed between two rigid walls considered as the masses [79]. These rigid walls stop a part of the sound according to the mass law: the heavier and denser a material, the higher the acoustic insulation is. The growing environmental awareness triggered a shift towards more environmentally friendly materials from renewable resources, such as waste wool and recycled polyester fibers [80]. Wooden fiber is good for acoustic since it is quite heavy but also mineral wool that has a good absorption factor at all frequencies [81,82].

Frames can be created in front of the existing walls separating the apartments from the common stairs/area, in which the insulation will be placed. For optimal insulation, the frame must be detached from the wall. That way, if one wall vibrates, it does not transmit its vibration to the second wall.

\section{Lighting conditions}

Ensuring good natural lighting conditions in a building is important to improve the health and wellbeing of residents [83]. A solution to enhance natural lighting in buildings would have been putting larger windows, but the cultural heritage regulations make this impossible. The alternative solution is to choose colors that reflect natural light. The reflection value of light can vary from very high percentage for white glossy finish to almost null for mat black. This can affect daylight illuminance in the room and impact the visual comfort of residents [84]. Finally, improving the artificial light equipment in the rooms can contribute to better conditions.

\section{Windows}

One solution will be to use windows with the lower U-value than windows already installed in order to reduce heat loss through window, especially in the north façade where there is the least solar gain [85-87]. However, windows with low U-Value are expensive and have a lower transmittance which deteriorates the properties of natural lighting [88]. A better performing frame like an insulated frame allows to reduce heat loss through the frame, and if they are well installed, they will highly reduce air leakage [89]. However, some of them could be expensive, and the design of the building does not allow to put any windows, as the external visual aspect must be kept. In the cheapest way, it is recommended to stop air leakage around the windows just with a seal and the use of reclaimed material to replace damaged parts. 


\section{Wind barrier}

Airtight building envelope in lightweight constructions in cold and moderate climates is normally realized by a continuous interior air- and vapor-tight barrier. However, a proper interior air barrier that fulfills the stricter environmental requirements is usually labor intensive due to many internal joints in buildings (e.g., interior walls, perforations necessary for electrical and plumbing devices) $[90,91]$.

Given the high possibility of unwanted infiltration of cold air in buildings through forced convection, using "wind barrier" can help to protect the outside insulation layer from such cold air infiltration into the constructions [92]. The wind barriers can also serve as a drainage plane to prevent water infiltration into the structure [92].

\section{Air leakage}

Uncontrolled infiltration of air through the building results from holes in the envelope (chimneys and ducts), gaps between building components especially at the roof, joints around movable elements such as doors and windows, and penetration of air through building components under pressure from wind. These infiltration means a high heat loss (up to $30 \%$ ). Reducing infiltration will therefore significantly reduce heat loss and reduce overconsumption [93]. The following actions can be taken to reduce infiltration:

- $\quad$ Replace air windows with low leakage units;

- Seal around door and window frames and other components with flexible mastic seal;

- $\quad$ Seal cracks and holes in the envelope, mainly around duct, pipe passage.

An old building breaths due to its air infiltration weaknesses, ventilation is mainly due to low airtightness. Therefore, in reducing air leaks, the building will be more airtight and this type of natural ventilation will be less efficient. It is important to consider ventilation in the renovation planning, in order to avoid reduction of inside air quality causing moisture, material degradation and health problems for the residents thereafter [94].

\section{Insulation of exterior components}

Given the considerable influence of building envelope properties on the construction energy performance, one of the most common methods to improve energy efficiency in constructions is to insulate the internal and external walls [95]. To minimize energy use in buildings, providing thermal and moisture insulation in the layers tend to be very efficient. Thermal insulation can be installed on the external or internal side of the building envelope. However, in case of historical buildings, applying insulation in the external walls should be done in a more careful way due to the necessity of preserving the ancient and distinctive appearance in such buildings [96].

However, the influence of moisture transfer and condensation inside the walls (which would affect the thermal performance of the materials as well) is usually overlooked. For instance, it is shown by Barbosa and Mendes (2008) [97] that ignoring the influence of moisture in thermal insulation layers may lead to underestimation of yearly heat flux in buildings, which will result in huge waste of energy. Hence, it is crucial to view both thermal and humidity aspects in installing insulation in both internal and external wall layers.

The given circumstances in Svartlamon offer both advantages and disadvantages in terms of wall insulation of external walls. The usual measures used in the performance of insulation techniques are usually characterized by a high-cost factor. However, Svartlamon has to deal with limited budgets. Due to this fact as well as the historical and heritage characteristics of buildings in this area, it is not advisable to install insulation in the outer shell of the building, as a composite thermal insulation system. On the contrary, techniques can be used which may differ slightly from the state of the art or which do not fully comply with the regulations. The loosened requirements for building standards in Svartlamon offer a great advantage in this respect. Thus, apart from fire protection, the energy standards for new buildings do not necessarily have to be fully met. In the following section, different possibilities will be explained which can lead to an enhancement of the living situation and comfort. 
Internal insulation is characterized by numerous disadvantages, as poor execution can result in extensive consequential damage [85]. Internal insulation in historical buildings can also lead to reduction of floor area, change of spatial room pro-portions, loss of historic fabric, and influence on the hygrothermal behavior of the insulated walls [98]. However, with careful execution it also offers several advantages with regard to Svartlamon. For instance, single rooms such as the living room can be insulated as desired to reduce heating times and energy loss. Although this means that valuable living space is lost, it also saves costs as no scaffolding is necessary, and the wooden cladding of the façade does not have to be removed and replaced.

Due, among other things, to the widespread use of timber-/timber-framed constructions in Norway, blow-in insulation should also be taken into consideration. With the help of this technique, all cavities are filled with loose bulk material and the insulating effect of the wall is significantly increased without a change in the external appearance of the building being visible after the measure. However, the installation should be carried out or at least supervised by a specialized company, since a deficient execution leads to large consequential damages. Nevertheless, it is a very cost-effective and above all very fast method with few working hours. There are also numerous sustainable and natural materials available for the choice of insulation material. For example, old newspapers can be collected and recycled to provide a much cheaper alternative to manufactured raw materials.

The structural and physical properties of the exterior walls are influenced by the right choice of materials and therefore also by the choice of insulating materials. Nowadays, many different insulating materials are used in the building industry. The Tables 4 and 5 were adapted from Gabriel and Ladener (2018) [99] and Kolb (2014) [100] and developed by one of the student [101] to be incorporated in the practical guidance and each give an overview of the individual properties of the selected insulating materials and techniques.

Table 4. Insulation materials and their properties (Beck, 2019).

\begin{tabular}{|c|c|c|c|c|c|c|}
\hline \multirow[t]{2}{*}{ Material } & Thickness $[\mathrm{cm}]$ & $\begin{array}{c}\text { Aprox.Cost }{ }^{*} \\
{\left[\mathrm{NOK} / \mathrm{m}^{2}\right]} \\
\mathrm{W} / \mathrm{m}^{2} \mathbf{k} \\
\end{array}$ & \multirow{2}{*}{$\begin{array}{l}\text { Primary Energy } \\
\text { Consumption } \\
{\left[\mathrm{kwh} / \mathrm{m}^{3}\right]}\end{array}$} & \multirow[t]{2}{*}{$\begin{array}{c}\text { Heat Insulation } \\
\text { Effect }\end{array}$} & \multirow[t]{2}{*}{$\begin{array}{l}\text { Summer Heat } \\
\text { Protection }\end{array}$} & \multirow[t]{2}{*}{$\begin{array}{c}\text { Moisture } \\
\text { Control }\end{array}$} \\
\hline & \multicolumn{2}{|c|}{ For U-Value $=0.2 \mathrm{~W} / \mathrm{m}^{2} \mathrm{~K}$} & & & & \\
\hline Flax & 20 & $250-300$ & $200-400$ & $\bullet \bullet \bullet \bullet$ & $\bullet \bullet \bullet \circ 0$ & $\bullet \bullet \bullet \bullet$ \\
\hline Hemp & 22.5 & $200-300$ & $200-400$ & $\bullet \bullet \bullet \bullet$ & $\bullet \bullet \bullet \circ \circ$ & $\bullet \bullet \bullet \bullet$ \\
\hline $\begin{array}{l}\text { Mineral bonded } \\
\text { wood wool } \\
\text { board }\end{array}$ & 45 & $750-950$ & 450 & $\bullet \bullet \bullet \circ$ & $\bullet \bullet \bullet \bullet$ & $\bullet \bullet \bullet \bullet$ \\
\hline Sheep wool & 20 & $350-600$ & $40-80$ & $\bullet \bullet \bullet \bullet$ & $\bullet 0000$ & $\bullet \bullet \bullet \bullet \bullet$ \\
\hline $\begin{array}{l}\text { Cellulose } \\
\text { (a) loose } \\
\text { (b) panels }\end{array}$ & $20-22.5$ & $\begin{array}{l}150-200 \\
250-300\end{array}$ & $\begin{array}{c}25-30 \\
100-600\end{array}$ & $\bullet \bullet \bullet \bullet$ & $\bullet \bullet \bullet \circ$ & 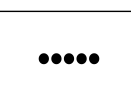 \\
\hline $\begin{array}{l}\text { Calcium silicate } \\
\text { boards }\end{array}$ & $50-100$ & $250(50 \mathrm{~mm})$ & - & $\bullet \bullet \bullet \circ$ & - & $\bullet \bullet \bullet \bullet$ \\
\hline $\begin{array}{l}\text { Mineralfiber } \\
\text { (a) glass wool } \\
\text { (b) rock wool }\end{array}$ & $17.5-25$ & $100-300$ & 95 & $\bullet \bullet \bullet \bullet \bullet$ & $\bullet \bullet \circ 00$ & 00000 \\
\hline $\begin{array}{l}\text { Expanded perlite } \\
\text { (a) thermal } \\
\text { insulation } \\
\text { (b) impact sound } \\
\text { insulation }\end{array}$ & $22.5-30$ & $200-400$ & $300-500$ & $\bullet \bullet \bullet \circ$ & $\bullet \bullet \bullet \circ$ & 00000 \\
\hline $\begin{array}{l}\text { Polystyrene } \\
\text { panels } \\
\text { (a) EPS } \\
\text { (b) XPS }\end{array}$ & $12.5-20$ & $\begin{array}{l}100-150 \\
400-500\end{array}$ & $\begin{array}{l}360-600 \\
600-900\end{array}$ & $\bullet \bullet \bullet \bullet \bullet$ & $\bullet \bullet \circ 00$ & 00000 \\
\hline
\end{tabular}


Table 5. Insulation techniques and their potential for self-renovation (Beck, 2019).

\begin{tabular}{|c|c|c|c|c|c|c|c|}
\hline & $\begin{array}{c}\text { Sustainable } \\
\text { Raw Materials } \\
\text { Usable }\end{array}$ & $\begin{array}{l}\text { Change in } \\
\text { Facade } \\
\text { Appearance }\end{array}$ & $\begin{array}{c}\text { Thermal } \\
\text { Bridge } \\
\text { Reduction to a } \\
\text { Minimum }\end{array}$ & $\begin{array}{l}\text { Fire Protection } \\
\text { Improvement }\end{array}$ & $\begin{array}{c}\text { Personal } \\
\text { Contribution } \\
\text { Possible }\end{array}$ & $\begin{array}{c}\text { Area of } \\
\text { Application }\end{array}$ & $\begin{array}{c}\text { Costs } \\
{\left[\text { NOK/m } / \mathrm{m}^{2}\right] \text { at }} \\
\text { Thickness t } \\
{[\mathrm{cm}]}\end{array}$ \\
\hline Curtain wall & $\bullet \bullet \bullet \bullet \bullet$ & $\bullet \bullet \bullet \bullet \bullet$ & $\bullet \bullet \bullet \bullet \circ$ & $\bullet \circ 000$ & $\bullet \bullet \bullet \bullet$ & $\begin{array}{l}\text { All building } \\
\text { types }\end{array}$ & $\begin{array}{l}1300-1700 \\
t=16\end{array}$ \\
\hline $\begin{array}{l}\text { Thermal } \\
\text { insulation } \\
\text { composite } \\
\text { system }\end{array}$ & $\bullet \bullet \bullet \circ)$ & $\bullet \bullet \bullet \circ \circ$ & $\bullet \bullet \bullet \bullet \bullet$ & $\bullet \bullet \bullet \circ O$ & $\bullet \circ \circ \circ)$ & $\begin{array}{l}\text { All building } \\
\text { types }\end{array}$ & $\begin{array}{l}1100-1500 \\
t=10\end{array}$ \\
\hline $\begin{array}{l}\text { Internal } \\
\text { insulation }\end{array}$ & $\bullet \bullet \circ \circ d$ & 100000 & $\bullet \bullet \circ \circ d$ & $\bullet 0000$ & $\bullet \bullet \circ \circ d$ & Listed facades & $\begin{array}{l}900-1200 ; \\
t=10\end{array}$ \\
\hline $\begin{array}{l}\text { Blow-in } \\
\text { insulation }\end{array}$ & $\bullet \bullet \bullet \bullet \bullet$ & 100000 & $\bullet$ & 100000 & $|00000|$ & $\begin{array}{l}\text { Double-shell } \\
\text { wall } \\
\text { (cavities } \\
\text { needed) }\end{array}$ & 150-300; \\
\hline $\begin{array}{l}\text { Insulation } \\
\text { plaster }\end{array}$ & 00000 & $\bullet \bullet \bullet \bullet$ & $\bullet \bullet \bullet \bullet \circ$ & $\bullet \bullet \bullet \bullet O$ & $\bullet \circ \circ \circ$ & $\begin{array}{l}\text { All building } \\
\text { types }\end{array}$ & 600-800; \\
\hline $\begin{array}{l}\text { Above rafter } \\
\text { insulation }\end{array}$ & $\bullet \bullet \bullet \bullet \bullet$ & $\bullet \bullet \bullet \circ \circ$ & $\bullet \bullet \bullet \bullet \bullet$ & $\bullet \circ 000$ & $\bullet \bullet \bullet \bullet$ & $\begin{array}{l}\text { Rafter roof } \\
\text { construction }\end{array}$ & 2000-2500; \\
\hline $\begin{array}{l}\text { Between- } \\
\text { /under- rafter } \\
\text { insulation }\end{array}$ & $\bullet \bullet \bullet \bullet \bullet$ & $\bullet \circ 000$ & $\bullet \bullet \circ 0$ & $\bullet \circ 000$ & $\bullet \bullet \bullet \bullet \circ$ & $\begin{array}{l}\text { Rafter roof } \\
\text { construction }\end{array}$ & 400-600; \\
\hline $\begin{array}{l}\text { Attic } \\
\text { insulation }\end{array}$ & $\bullet \bullet \bullet \bullet \bullet$ & 100000 & $\bullet \bullet \bullet \bullet \circ$ & $\bullet \circ 000$ & $\bullet \bullet \bullet \bullet \bullet$ & $\begin{array}{l}\text { All building } \\
\text { types }\end{array}$ & 400-600; \\
\hline
\end{tabular}

Provided information consists of approximate costs per square meter for the materials and their technical parameters as well as indications regarding insulation techniques that could be more or less easily applicable for self-renovation work. A point system is used to describe the insulating efficiency, summer heat protection, and moisture control (Table 4), whereby five filled out points stand for very high (very good) and five empty points for low (very bad). The same point system is used to assess the insulation techniques (Table 5).

\section{Discussion and Conclusions}

The purpose of this study was to explore the challenges related to sustainable refurbishment of an experimental urban ecological area with a strong historical and cultural heritage. We proposed possible renovation solutions and instructions with respect to the self-renovation culture that dominates in the community while also accounting for the complex ownership structure, governance, and insufficient funds for the maintenance backlog. Findings from this paper provided insight in two aspects of self-renovation:

(i) Available resources and reuse of materials;

(ii) Renovation guidance for inhabitants from the building physics perspective and improvements to the indoor comfort.

The research prepared together with master's students from NTNU is based on on-site observation and a close collaboration with the housing foundation of Svartlamon, thus providing solid basis for recommending real-life practical solutions that reflect the needs and the will of the community while trying to improve the overall sustainability of the building stock.

Based on the research, this study presents answers to the research question How to raise the self-renovation standards of a culturally protected although poorly maintained area?

Results show that in order to keep a sustainable, low-cost urban living model, instructions for self-renovation including information on their impact on sustainability are valuable as a guidance for non-professionals to make informed choices. We can emphasize that inhabitants are used to lower living standards, so the project is aimed to present the proper solutions for improvement as a balance between new technical solutions, personal self-renovation skills, habits, and health. This study addresses the challenges related to lack of motivation, knowledge, and communication that constitute major barriers to the implementation of sustainable renovation measures by proposing concrete actions based 
on state-of-the-art energy-retrofit interventions that account for the pre-existing cultural and economic factors influencing community decisions and capabilities.

The community has had a long history of fighting for the preservation of the area as a low-standard independent neighborhood. Despite of the maintenance backlog, the will of the community to work together to renovate the buildings is an asset. Having only a low budget and little knowledge, they constantly found creative ways to address their problems, for example, the infrastructure and network systems for re-using materials are already well implemented. However, the local storage of the materials is a limit to their ambitions, and the community as well as the municipality could benefit from being part of a wider network as proposed by Loopfront. This pre-existing culture should be combined with more sustainable solutions such as improving the thermal insulation, upgrading the windows with better glazing and frames, etc. With an improved maintenance strategy and access to the proper tools and resources, the community could develop their self-renovation culture towards more efficient and environmentally friendly practices.

Recommendations for future self-renovation work should provide some key-knowledge to the inhabitants about insulation, structure, indoor climate, building physics, and energy efficiency. This would allow them to make better-informed choices when engaging in self-renovation projects. All aspects of a renovation plan are closely linked and should be considered simultaneously. For instance, repairment, sealing of cracks and sealing of air infiltration weaknesses, adding new layers like wind barrier and insulation lead to buildings more airtight which means that ventilation system must be considered and improved. Regarding the indoor comfort in the building, it is relevant to point out that they were not initially designed for the modern lifestyle and hygiene habits; inhabitants activities and use of the kitchens and bathrooms have caused humidity damages that should be fixed in order to insure an acceptable indoor air quality.

Furthermore, when developing a practical maintenance guide, the effects and the actual cost-benefit factor for the residents of Svartlamon must also be considered, and a balance must be found between technical solutions and user behavior.

To improve the living standards in Svartlamon, thermal comfort and building physics, the proposed solutions and recommendations aforementioned might be a promising start to sustainably improve the houses in the long-term.

Author Contributions: Conceptualization, C.S., A.T.S. and M.V.; formal analysis, C.S., A.T.S. and M.V.; investigation, C.S. and Ž.K.; methodology, C.S. and A.T.S.; resources, Ž.K.; supervision, A.T.S.; visualization, M.J.; writing—original draft, C.S., A.T.S. and M.V.; writing—review and editing, C.S., A.T.S., M.V., M.J. and Ž.K. All authors have read and agreed to the published version of the manuscript.

Funding: This research received no external funding.

Institutional Review Board Statement: Not applicable.

Informed Consent Statement: Not applicable.

Acknowledgments: The authors would like to thank all the master students who took part in the course "Refurbishment technology Specialized course" at NTNU Faculty of Civil ad Environmental Engineering since 2018 for their work and their innovative thinking which are the foundations of this paper.

Conflicts of Interest: The authors declare no conflict of interest.

\section{References}

1. Lidelöw, S.; Örn, T.; Luciani, A.; Rizzo, A. Energy-efficiency measures for heritage buildings: A literature review. Sustain. Cities Soc. 2019, 45, 231-242. [CrossRef]

2. Loli, A.; Bertolin, C. Towards zero-emission refurbishment of historic buildings: A literature review. Buildings 2018, 8, 22. [CrossRef]

3. Terama, E.; Peltomaa, J.; Mattinen-Yuryev, M.; Nissinen, A. Urban Sustainability and the SDGs: A Nordic Perspective and Opportunity for Integration. Urban Sci. 2019, 3, 69. [CrossRef] 
4. Esser, A.; Dunne, A.; Meeusen, T.; Quaschning, S.; Denis, W. Comprehensive Study of Building Energy Renovation Activities and the Uptake of Nearly Zero-Energy Buildings in the EU Final Report; European Commission: Brussels, Belgium, 2019; 87p.

5. Burman, E.; Mumovic, D. Measurement and Verification Models for Cost-Effective Energy-Efficient Retrofitting; Elsevier: Amsterdam, The Netherlands, 2017; ISBN 9780081011287.

6. Lucchi, E.; Delera, A.C. Enhancing the historic public social housing through a user-centered design-driven approach. Buildings 2020, 10, 159. [CrossRef]

7. Abdellatif, M.; Al-Shamma'a, A. Review of sustainability in buildings. Sustain. Cities Soc. 2015, 14, 171-177. [CrossRef]

8. Semprini, G.; Gulli, R.; Ferrante, A. Deep regeneration vs shallow renovation to achieve nearly Zero Energy in existing buildings: Energy saving and economic impact of design solutions in the housing stock of Bologna. Energy Build. 2017, 156. [CrossRef]

9. Gianfrate, V.; Piccardo, C.; Longo, D.; Giachetta, A. Rethinking social housing: Behavioural patterns and technological innovations. Sustain. Cities Soc. 2017, 33. [CrossRef]

10. McCabe, A.; Pojani, D.; van Groenou, A.B. The application of renewable energy to social housing: A systematic review. Energy Policy 2018, 114. [CrossRef]

11. Guarini, M.R. Self-renovation in Rome: Ex ante, in itinere and ex post evaluation. In Computational Science and Its Applications, Proceedings of the ICCSA 2016 Conference, Beijing, China, 4-7 July 2016; Lecture Notes in Computer Science (including subseries Lecture Notes in Artificial Intelligence and Lecture Notes in Bioinformatics); Springer: Berlin/Heidelberg, Germany, 2016; Volume 9789, pp. 204-218. ISBN 9783319420882.

12. Risholt, B.; Berker, T. Success for energy efficient renovation of dwellings-Learning from private homeowners. Energy Policy 2013, 61, 1022-1030. [CrossRef]

13. Godbolt, Å.L.; Flyen, C.; Hauge, Å.L.; Flyen, A.C.; Moen, L.L. Future resilience of cultural heritage buildings—How do residents make sense of public authorities' sustainability measures? Int. J. Disaster Resil. Built Environ. 2018, 9, 18-30. [CrossRef]

14. Xue, Y.; Temeljotov-Salaj, A.; Engebø, A.; Lohne, J. Multi-sector partnerships in the urban development context: A scoping review. J. Clean. Prod. 2020, 268, 122291. [CrossRef]

15. Hauge, Å.L.; Hanssen, G.S.; Flyen, C. Multilevel networks for climate change adaptation—What works? Int. J. Clim. Chang. Strateg. Manag. 2019, 11. [CrossRef]

16. Kobal Grum, D. Interactions between human behaviour and the built environment in terms of facility management. Facilities 2018, 36. [CrossRef]

17. Grum, B.; Kobal Grum, D. Concepts of social sustainability based on social infrastructure and quality of life. Facilities 2020, 38 . [CrossRef]

18. Bissonnette, J.F.; Dupras, J.; Messier, C.; Lechowicz, M.; Dagenais, D.; Paquette, A.; Jaeger, J.A.G.; Gonzalez, A. Moving forward in implementing green infrastructures: Stakeholder perceptions of opportunities and obstacles in a major North American metropolitan area. Cities 2018, 81. [CrossRef]

19. Gan, X.; Chang, R.; Wen, T. Overcoming barriers to off-site construction through engaging stakeholders: A two-mode social network analysis. J. Clean. Prod. 2018, 201. [CrossRef]

20. Le Feuvre, M.; Medway, D.; Warnaby, G.; Ward, K.; Goatman, A. Understanding stakeholder interactions in urban partnerships. Cities 2016, 52. [CrossRef]

21. Hein, A.M.; Jankovic, M.; Feng, W.; Farel, R.; Yune, J.H.; Yannou, B. Stakeholder power in industrial symbioses: A stakeholder value network approach. J. Clean. Prod. 2017, 148. [CrossRef]

22. Yang, A.; Bentley, J. A balance theory approach to stakeholder network and apology strategy. Public Relat. Rev. 2017, 43. [CrossRef]

23. Tyl, B.; Vallet, F.; Bocken, N.M.P.; Real, M. The integration of a stakeholder perspective into the front end of eco-innovation: A practical approach. J. Clean. Prod. 2015, 108. [CrossRef]

24. Aoki, N. Sequencing and combining participation in urban planning: The case of tsunami-ravaged Onagawa Town, Japan. Cities 2018, 72. [CrossRef]

25. Ferguson, L.; Chan, S.; Santelmann, M.; Tilt, B. Exploring participant motivations and expectations in a researcher-stakeholder engagement process: Willamette Water 2100. Landsc. Urban Plan. 2017, 157. [CrossRef]

26. Li, H.; de Jong, M. Citizen participation in China's eco-city development. Will 'new-type urbanization' generate a breakthrough in realizing it? J. Clean. Prod. 2017, 162. [CrossRef]

27. Temeljotov Salaj, A.; Gohari, S.; Senior, C.; Xue, Y.; Lindkvist, C. An interactive tool for citizens' involvement in the sustainable regeneration. Facilities 2020, 38, 859-870. [CrossRef]

28. Temeljotov Salaj, A.; Lindkvist, C.M. Urban facility management. Facilities 2021, 39, 525-537. [CrossRef]

29. Esmaeilpoorarabi, N.; Yigitcanlar, T.; Kamruzzaman, M.; Guaralda, M. How can an enhanced community engagement with innovation districts be established? Evidence from Sydney, Melbourne and Brisbane. Cities 2020, 96. [CrossRef]

30. Fleiß, E.; Hatzl, S.; Seebauer, S.; Posch, A. Money, not morale: The impact of desires and beliefs on private investment in photovoltaic citizen participation initiatives. J. Clean. Prod. 2017, 141. [CrossRef]

31. Swapan, M.S.H. Who participates and who doesn't? Adapting community participation model for developing countries. Cities 2016, 53. [CrossRef]

32. Foultier, C. Empowering the Unprivileged: The Case of Self-renovation in Disadvantaged Areas. In Current Issues in European Cultural Studies, Linköping Electronic Conference Proceedings, Norrköping, Sweden, 15-17 June 2011; Linköping University Electronic Press: Linköping, Sweeden, 2011; pp. 545-551. 
33. Royston, S.; Foulds, C. The making of energy evidence: How exclusions of Social Sciences and Humanities are reproduced (and what researchers can do about it). Energy Res. Soc. Sci. 2021, 77, 102084. [CrossRef]

34. Overland, I.; Sovacool, B.K. The misallocation of climate research funding. Energy Res. Soc. Sci. 2020, 62, 101349. [CrossRef]

35. Baum, C.M.; Bartkowski, B. It's not all about funding: Fostering interdisciplinary collaborations in sustainability research from a European perspective. Energy Res. Soc. Sci. 2020, 70, 101723. [CrossRef]

36. Norwegian Government Bygningsvern i Norge. Available online: https://www.regjeringen.no/no/tema/klima-og-miljo/ kulturminner-og-kulturmiljo/innsiktsartikler-kulturminner/bygningsvern-i-norge/id2343540/ (accessed on 20 May 2021).

37. Det Kongelige Miljøverndepartementet. Living with our Cultural Heritage St.meld. nr. 16 (2004-2005); Norwegian Government: Oslo, Norway, 2005; Volume 16.

38. Bystrategi 2017-2020; Riksantikvaren: Oslo, Norway, 2017.

39. Igor, S.; Wachenfeldt, B.J.; Anne Grete, H. Energy demand in the Norwegian building stock: Scenarios on potential reduction. Energy Policy 2009, 37, 1614-1627. [CrossRef]

40. Ugarte, S.; Van Der Ree, B.; Voogt, M.; Eichhammer, W.; Ordoñez, J.A.; Reute, M.; Schlomann, B.; Llore, P.; Villafáfila, R. Policy Department: Economic and Scientific Policy-Energy Efficiency for Low-Income Households; European Parliament: Brussels, Belgium, 2016.

41. Talbot, J. Mobilizing Energy Efficiency in the Manufactured Housing Sector; American Council for an Energy-Efficient Economy: Washington, DC, USA, 2012; Volume 20045.

42. Stieß, I.; Dunkelberg, E. Objectives, barriers and occasions for energy efficient refurbishment by private homeowners. J. Clean. Prod. 2013, 48, 250-259. [CrossRef]

43. Humar, M.; Lesar, B.; Kržišnik, D. Moisture Performance of Façade Elements Made of Thermally Modified Norway Spruce Wood. Forests 2020, 11, 348. [CrossRef]

44. Zafar, F.; Sharmin, E.; Ashraf, S.M.; Ahmad, S. Ambient-cured polyesteramide-based anticorrosive coatings from linseed oil-A sustainable resource. J. Appl. Polym. Sci. 2005, 97, 1818-1824. [CrossRef]

45. Larsen, K.E.; Nils, M. Conservation of Historic Timber Structures an Ecological Approach; Butterworth-Heinemann Series in Conservation and Museology; Reed Educational and Professional Publishing Ltd.: Oxford, UK, 2000.

46. Lisø, K.R.; Kvande, T.; Time, B. Climate Adaptation Framework for Moisture-resilient Buildings in Norway. Energy Procedia 2017, 132, 628-633. [CrossRef]

47. Kristl, Ž.; Senior, C.; Temeljotov Salaj, A. Key challenges of climate change adaptation in the building sector. Urbani Izziv 2020, 31, 101-111. [CrossRef]

48. Bradshaw, J.L.; Bou-Zeid, E.; Harris, R.H. Comparing the effectiveness of weatherization treatments for low-income, American, urban housing stocks in different climates. Energy Build. 2014, 69, 535-543. [CrossRef]

49. Zavadskas, E.K.; Kaklauskas, A.; Tupenaite, L.; Mickaityte, A. 2008. Decision-Making Model for Sustainable Buildings Refurbishment. Energy Efficiency Aspect. In Proceedings of the 7th International Conference on Environmental Engineering, ICEE, Vilnius, Lithuania, 22-23 May 2008; pp. 894-901.

50. Korjenic, A.; Zach, J.; Hroudová, J. The use of insulating materials based on natural fibers in combination with plant facades in building constructions. Energy Build. 2016, 116, 45-58. [CrossRef]

51. Pye, M. Energy Efficiency Programs for Low-Income Households: Successful Approaches for a Competitive Environment; American Council for an Energy-Efficient Economy: Washington, DC, USA, 1996; Volume 20036.

52. Underhill, L.J.; Milando, C.W.; Levy, J.I.; Dols, W.S.; Lee, S.K.; Fabian, M.P. Simulation of indoor and outdoor air quality and health impacts following installation of energy-efficient retrofits in a multifamily housing unit. Build. Environ. 2020, 170, 106507. [CrossRef]

53. New European Bahaus-Initiative European Commission. Why the New European Bauhaus (NEB)? What Are the Next Concrete Steps? European Commission: Brusels, Belgium, 2021.

54. Hermelink, A.; Schimschar, S.; Offermann, M.; John, A.; Reiser, M.; Pohl, A.; Grözinger, J. Comprehensive Study of Building Energy Renovation Activities and the Uptake of Nearly Zero-Energy Buildings in the EU; European Commission: Cologne, Germany, 2019.

55. Trouillon, D.; Gendarme, E.; Mouton, L.; Dehon, O.; Pauchon, S.; Beck Heremans, V.; Sekkal, Y. How to Improve the Living Standard of Inhabitants of Svartlamon in a Sustainable Way? Report for TBA4178-Refurbishment Technology Specialised Course; NTNU: Trondheim, Norway, 2019.

56. Berge, I.C.M.; Horten, H.; Hua, C.R.R.; Knudsen, A.H.V.; Solli, C.J.; Pérez Celaya, N. Sustainable Refurbishment at Biskop Darres Gate 10, Svartlamon; Report for TBA4178 Course "Refurbishment Technology Specialised"; NTNU: Trondheim, Norway, 2020.

57. EUROPAN 10 Comittee. EUROPAN10 Trondheim, Norway 2010. Available online: http://europan.no/ukategorisert/e10-thesites / (accessed on 20 May 2021).

58. Øverland Gater, P. Historieglimt 7; Lademoen Kirkes Småskrifter: Trondheim, Norway, 2011.

59. Leuraers, C.; van Dooren, A.; Bjørberg, S.; Temeljotov Salaj, A. Alternative Community—Promotor or Inhibitor of Sustainable Development. In Keeping up with Technologies to Turn Built Heritage into the Places of Future Generations, Conference Proceedings, 6th International Academic Conference on Places and Technologies, Pecs, Hungary, 9-10 May 2019; University of Pecs Faculty of Engineering and Information Technology: Pecs, Hungary, 2019; pp. 582-590.

60. Sager, T. Planning by intentional communities: An understudied form of activist planning. Plan. Theory 2018, 17, 449-471. [CrossRef] 
61. Kozeny, G. Intentional Communities: Lifestyles Based on Ideals. In Communities Directory: A Guide to Cooperative Living; Fellowship for Intentional Community: Langley, DC, USA, 1995; pp. 18-24.

62. Lowenstein, O. Svartlamoen's Ragged Glory-Where Alt-Culture Meets Avant Timber Architecture. Available online: http: //www.fourthdoor.co.uk/unstructured/unstructured_08/svartlamon.php (accessed on 10 May 2021).

63. Svartlamon Webgruppe Hva er Svartlamon-Organisering. Available online: https://svartlamon.org/organisering/ (accessed on 10 May 2021).

64. Vukmirović, M.; Nikolić, M. Industrial heritage preservation and the urban revitalisation process in Belgrade. J. Urban Aff. 2021. [CrossRef]

65. Salaj, A.T.; Lindkvist, C.; Jowkar, M. Social needs for sustainable refurbishment in Trondheim. In Proceedings of the 19th EuroFM Research Symposium 2020, Online. 3-4 June 2020; pp. 51-61.

66. Jowkar, M.; Temeljotiv-Salaj, A.; Lindkvist, C.M.; Støre-Valen, M. Sustainable Building Renovations: Barriers and Potential Motivations. Constr. Manag. Econ. 2021, in press.

67. Kulenović, R. MOGUĆNOSTI (Re)Aktivacije Napuštenih Industrijskih Objekata: Raskršća i Putokazi (Possibilities for (Re)Activation of Vacant Industrial Buildings: Crossroads and Road Signs); Kulturklammer-Centar za Kulturne Interakcije: Belgrade, Serbia, 2008. (In Serbian)

68. Trondheim Municipality. R 219b-Bestemmelser til Endret Reguleringsplan for Svartlamoen (Reinaområdet); Trondheim Municipality: Trondheim, Norway, 2006; pp. 1-10.

69. Municipal Council of Trondheim. Saksdokumenter-Sak PS 0193/16-Evaluaering Av Svartlamon; Municipal Council of Trondheim: Trondheim, Norway, 2016.

70. Wahlström, M.; Castell-Rüdenhausen, M.; Astrup, T.F.; Oberender, A.; Jensen, C.; Johansson, P.; Wærner, E. Strategies and Methods for Implementing CE in Construction Activities in the Nordic Countries-Supporting Cases, 508th ed.; Nordic Council of Ministers, Ed.; Nordic Energy Research, Nordisk Ministerråd: Copenhagen, Denmark, 2021; ISBN 9789289369299.

71. Madsø, F. Lilleborg Gjenbruk av Tegl Raporter; NCC Statsbygg: Oslo, Norway, 2001.

72. Kilvær, L.; Sunde, O.W.; Eid, M.S.; Rydningen, O.; Fjeldheim, H. Forsvarlig Ombruk av Byggevarer. 2019. Available online: https: / / dibk.no/globalassets/02.-om-oss/rapporter-og-publikasjoner/forsvarlig-ombruk-av-byggevarer_resirqel-2019.pdf (accessed on 20 May 2021).

73. Pettersen, N. Gjenbrukshus i Trondheim; Miljøenheten in Trondheim Kommune: Trondheim, Norway, 2005 ; ISBN 8277270917. (In Norwegian)

74. Sørnes, K.; Nordby, A.S.; Fjeldheim, H.; Hashem, S.M.B.; Mysen, M.; Dahl Schlanbusch, R. Anbefalinger ved Ombruk av Byggematerialer; Sintef: Trondheim, Norway, 2014.

75. Walker, A. Natural Ventilation. 2016. Available online: https://www.wbdg.org/resources/natural-ventilation (accessed on 20 May 2021).

76. Nunes de Freitas, P.; Guedes, M.C. The use of windows as environmental control in "Baixa Pombalina's" heritage buildings. Renew. Energy 2015, 73, 92-98. [CrossRef]

77. Atkinson, J.; Yves, C.; Pessoa-Silva, C.-L.; Jensen, P.; Li, Y.; Seto, W.-H. Natural Ventilation for Infection Control in Health-Care Settings; Atkinson, J., Chartier, Y., Pessoa-Silva, C.L., Jensen, P., Li, Y., Seto, W.-H., Eds.; WHO Press: Geneva Switzerland, 2009.

78. Lin, Y.-P.; Iba, C.; Lai, C.-M. Natural Ventilation Effectiveness of Round Wall-Mounted Vent Caps in Residential Kitchens. Energies 2018, 11, 1230. [CrossRef]

79. Rasmussen, B. Sound insulation between dwellings-Requirements in building regulations in Europe. Appl. Acoust. 2010, 71, 373-385. [CrossRef]

80. Patnaik, A.; Mvubu, M.; Muniyasamy, S.; Botha, A.; Anandjiwala, R.D. Thermal and sound insulation materials from waste wool and recycled polyester fibers and their biodegradation studies. Energy Build. 2015, 92, 161-169. [CrossRef]

81. Zhao, J.; Wang, X.M.; Chang, J.M.; Yao, Y.; Cui, Q. Sound insulation property of wood-waste tire rubber composite. Compos. Sci. Technol. 2010, 70, 2033-2038. [CrossRef]

82. Zhu, X.; Kim, B.J.; Wang, Q.W.; Wu, Q. Recent advances in the sound insulation properties of bio-based materials. BioResources 2014, 9, 1764-1786. [CrossRef]

83. Dovjak, M.; Košir, M.; Kristl, Ž.; Krainer, A. Assessment of Sustainability Aspects of Daylighting in Buildings. In Proceedings of the Euro Sun Conference, Aix-les-Bains, France, 16-17 September 2015; ISBN 9783981465938.

84. Pajek, L.; Košir, M.; Kristl, Ž.; Kacjan Žgajnar, K.; Dovjak, M. Indoor evnironmental quality (IEQ) in Slovenian children daycare centres. Part I: Results of in-situ measurements. Int. J. Sanit. Eng. Res. 2017, 11, 27.

85. Blecich, P.; Franković, M.; Kristl, Ž. Energy retrofit of the Krsan Castle: From sustainable to responsible design—A case study. Energy Build. 2016, 122, 23-33. [CrossRef]

86. Košir, M.; Gostiša, T.; Kristl, Ž. Influence of architectural building envelope characteristics on energy performance in Central [European climatic conditions. J. Build. Eng. 2018, 15, 278-288. [CrossRef]

87. Kristl, Z.; Zbasnik-senegacnik, M. Energy Renovation of Large Neighbourhoods in Slovenia. In Proceedings of the Fourth ISES-Europe Solar Congress, Bologna, Italy, 23-26 June 2002; Renewable Energy for Local Communities of Europe, Toward Rio+10. International Solar Energy Society: Trento, Italy, 2000; pp. 1-8.

88. Garnier, C.; Muneer, T.; McCauley, L. Super insulated aerogel windows: Impact on daylighting and thermal performance. Build. Environ. 2015, 94, 231-238. [CrossRef] 
89. Burattini, C.; Nardecchia, F.; Bisegna, F.; Cellucci, L.; Gugliermetti, F.; De Lieto Vollaro, A.; Salata, F.; Golasi, I. Methodological approach to the energy analysis of unconstrained historical buildings. Sustainability 2015, 7, 10428-10444. [CrossRef]

90. Aho, H.; Vinha, J.; Korpi, M. Implementation of airtight constructions and joints in residential buildings. In Proceedings of the 8th Nordic Building Physics Symposium, Copenhagen, Denmark, 16-18 June 2008; Technical University of Denmark: Twente, Danemark, 2008.

91. Kalamees, T. Air tightness and air leakages of new lightweight single-family detached houses in Estonia. Build. Environ. 2007, 42, 2369-2377. [CrossRef]

92. Langmans, J.; Klein, R.; Eykens, P.; De Paepe, M.; Roels, S. Feasibility of using wind barriers as air barriers in wood frame construction. In Proceedings of the International Conference on Thermal Performance of the Exterior Envelopes of Whole Buildings, Buildings XI, Clearwater, FL, USA, 5-10 December 2010.

93. Martín-Garín, A.; Millán-García, J.A.; Hidalgo-Betanzos, J.M.; Hernández-Minguillón, R.J.; Baïri, A. Airtightness analysis of the built heritage-field measurements of nineteenth century buildings through blower door tests. Energies 2020, 13, 6727. [CrossRef]

94. Boro, M. Veileder-Råd om Energisparing i Gamle Hus; Riksantikvaren: Oslo, Norway, 2013; ISBN 9788275740807.

95. Yan, L.; Liu, C. Techno-economic analysis for constructing solar photovoltaic projects on building envelopes. Build. Environ. 2018, 127, 37-46.

96. Xu, C.; Shuhong, L.; Zou, K. Study of heat and moisture transfer in internal and external wall insulation configurations. Build. Eng. 2019, 24, 100724. [CrossRef]

97. Barbosa, R.M.; Mendes, N. Combined simulation of central HVAC systems with a whole-building hygrothermal model. Energy Build. 2008, 40, 276-288. [CrossRef]

98. Harrestrup, M.; Svendsen, S. Internal insulation applied in heritage multi-storey buildings with wooden beams embedded in solid masonry brick façades. Build. Environ. 2016, 99, 59-72. [CrossRef]

99. Gabriel, I.; Ladener, H. Vom Altbau zum Effizienzhaus; Ökobuch: Staufen im Breisgau, Germany, 2018; ISBN 9783936896756.

100. Kolb, B. Altbausanierung mit Nachwachsenden Rohstoffen (Renovation of Old Buildings with Renewable Raw Materials); Fachagentur Nachwachsende Rohstoffe: Gülzow, Germany, 2014.

101. Beck, S. Insulation Improvement Considering Sustainable and Ecological Aspects; Report for TBA4178 Course "Refurbishment Technology Specialised"; NTNU: Trondheim, Norway, 2019. 